\begin{tabular}{|l|l|l||}
\hline \multicolumn{2}{|c|}{ PublisherInfo } \\
\hline \hline PublisherName & $:$ & BioMed Central \\
\hline \hline PublisherLocation & $:$ & London \\
\hline \hline PublisherImprintName & $:$ & BioMed Central \\
\hline \hline
\end{tabular}

\title{
A reference tool for cytochrome P450 drug interactions
}

\begin{tabular}{|l|l|l||}
\hline \multicolumn{2}{|c||}{ ArticleInfo } \\
\hline \hline ArticleID & $:$ & 4297 \\
\hline \hline ArticleDOI & $:$ & $10.1186 /$ ccf-2000-webreport521 \\
\hline \hline ArticleCitationID & $:$ & webreport521 \\
\hline \hline ArticleSequenceNumber & $:$ & 38 \\
\hline \hline ArticleCategory & $:$ & Web report \\
\hline \hline ArticleFirstPage & $:$ & 1 \\
\hline \hline ArticleLastPage & $:$ & 2 \\
\hline \hline & $:$ & RegistrationDate : 2000-10-11 \\
ArticleHistory & $:$ & OnlineDate \\
\hline \hline ArticleCopyright & $:$ & Current Science Ltd2000-10-11 \\
\hline \hline ArticleGrants & $:$ & \\
\hline \hline ArticleContext & $:$ & 1305444 \\
\hline \hline
\end{tabular}




\section{Background}

In addition to an international registry for drug-induced arrythmias (see previous web report published in the CCForum, 31-Oct-2000), Georgetown Medical Center have also established this important reference tool. It was designed for physicians and researchers interested in drug interactions that are the result of competition for, or effects on, the human cytochrome P450 system.

\section{Description}

The site consists of a table which lists drug names in columns under headings of specific cytochrome P450 isoforms. A drug appears in a column if there is published evidence that it is metabolised by the isoform under which it is listed. Beneath the list of drugs that are metabolised by a specific cytochrome P450, are the published inhibitors, inducers and genetic influences on that isoform. In addition, drug names are hyperlinked to relevant literature references. An abbreviated clinical table designed for use during prescribing is also available.

\section{Evaluation}

Despite it's plain appearance, the site contains a wealth of information. Furthermore, it is interactive, with physicians and researchers invited to suggest additions, deletions and references. Indeed, Dr David A. Flockhart who is responsible for updating the table, admits that it has benefited greatly from the input of practicing physicians and researchers.

\section{References}

1. Cytochrome P450 drug interaction table. [http://www.dml.georgetown.edu/depts/pharmacology/ davetab.html] 